\title{
Self-medication of antibiotics: investigating practice among university students at the Malaysian National Defence University
}

This article was published in the following Dove Press journal: Infection and Drug Resistance

\author{
Mainul Haque' \\ Nor Azlina A Rahman ${ }^{2}$ \\ Judy McKimm ${ }^{3}$ \\ Golam Mohammad Kibria' \\ Md Anwarul Azim Majumder ${ }^{4}$ \\ Seraj Zohurul Haque ${ }^{5}$ \\ Md Zakirul Islam ${ }^{6}$ \\ Shahidah Leong Binti Abdullah' \\ Aqil Mohammad Daher' \\ Zainal Zulkifli $^{7}$ \\ Sayeeda Rahman ${ }^{8}$ \\ Russell Kabir? \\ Siti Nur Najihah Binti Lutfi' \\ Nur Syamirah Aishah Binti \\ Othman'
}

'Faculty of Medicine and Defence Health, Universiti Pertahanan Nasional Malaysia (National Defence University of Malaysia), Kuala Lumpur, 57000, Malaysia; ${ }^{2}$ Department of Physical Rehabilitation Sciences, Kulliyyah of Allied Health Sciences, International Islamic University Malaysia, Kuantan, 25200, Malaysia; ${ }^{3}$ Swansea University School of Medicine, Grove Building, Swansea University, Swansea, Wales, SA2 8PP, UK;

${ }^{4}$ Department of Medical Education, Faculty of Medical Sciences, The University of the West Indies, Bridgetown, Barbados, West Indies;

${ }^{5}$ Department of Orthopedic Surgery, Ninewells Hospital \& Medical School, Dundee, DDI 9SY, Scotland, UK; ${ }^{6}$ Department of Pharmacology, Eastern Medical College, Burichang 3520, Bangladesh; ${ }^{7}$ Department of Surgery, Sultan Haji Ahmad Shah Hospital, Temerloh, Pahang, 28000, Malaysia; ${ }^{8}$ Department of Pharmacology and Public Health, School of Medicine, American University of Integrative Sciences, Bridgetown, Barbados; 'School of Allied Health, Faculty of Health, Education, Medicine and Social Care, Anglia Ruskin University, Chelmsford, Essex, UK

Correspondence: Mainul Haque Universiti Pertahanan Nasional Malaysia (National Defence University of Malaysia), Kem Perdana Sungai Besi, Kuala Lumpur 57000 , Malaysia

Tel +60 109265 543

Email runurono@gmail.com
Background: Self-medication of drugs to alleviate symptoms is a common global behavior, helping relieve burdens on health services, but many drugs eg, antibiotics are prescriptiononly. Self-medication of antibiotics (SMA) is an irrational use of drugs, contributing to microbial resistance increasing health care costs and higher mortality and morbidity. This study aimed to assess SMA among university students.

Methods: This was a cross-sectional study conducted among medical and non-medical students of the National Defence University of Malaysia. A validated instrument was used to gather data. Ethics approval was obtained. Random and universal sampling was adopted, and SPSS 21 was used for data analysis.

Results: A total of 649 students participated in the study: $48.5 \%$ male and $51.5 \%$ female, $39.3 \%$ reported self-medicating with antibiotics. Penicillin, doxycycline, clarithromycin were the antibiotics most used with the majority reporting no adverse drug reactions. Cost savings and convenience were the principal reasons for SMA which were mainly obtained from local retail pharmacies. Despite medical students (particularly the more senior) having better knowledge of antibiotic use than non-medical students, $89 \%$ of all research participants responded that practicing SMA was a good/acceptable practice.

Conclusion: SMA is common amongst Malaysian students and, despite understanding why SMA is unwise, even medical students self-medicate.

Keywords: antibiotics, self-medication, antibiotic resistance, university students, medical students, non-medical students

\section{Introduction}

The World Health Organization (WHO) defines self-medication as "the use of drugs to treat self-diagnosed disorders or symptoms, or the intermittent or continued use of a prescribed drug for chronic or recurrent disease or symptoms". 1 Self-medication of antibiotics (SMA) has been recognized as inappropriate and irrational use of antibiotics and overall self-medication is considered as irrational. ${ }^{2}$ Globally, the non-prescription consumption of antimicrobials has been growing and is recognized as a key risk factor for antimicrobial resistance (AMR). Because of this, in most of the countries legislation forbids patients from buying antimicrobials over the counter" as it seen "as fuelling the evolution of resistant microbes". However, in some countries (eg, Latin America) the law is often not executed, and patients can obtain such medicines without prescriptions. ${ }^{5}$ In Malaysia, the context of this study, antibiotics are 
supposed to be prescription-only medicines ${ }^{6}$ but, nevertheless, studies report that antimicrobials can be bought over the counter. ${ }^{7,8}$ Around the world, pathogenic microorganisms that were principally affecting hospital patients are also infecting people in the community. ${ }^{9-12}$ and multi-drug-resistance of diseases such as tuberculosis, malaria, and gonorrhea, which are usually treated in the community is being reported. ${ }^{13,14}$

Self-medication can also be defined "as the selection and use of medicines by individuals (or a member of the individuals' family) to treat self-recognized or selfdiagnosed conditions or symptoms." 15 It involves the procurement of medicines without a prescription; using old prescriptions to buy medicines; using surplus medicines from friends or relatives for similar symptoms, and giving medications to other household members or dependent relatives, eg, children and older family members. ${ }^{1,16}$ Selfmedication is one of the leading global causes of $\mathrm{AMR}^{17}$ and can lead to health hazards because of the wrong diagnosis; dosage; formulation; route; risk of adverse drug reactions; and drug interactions. ${ }^{15}$ SMA can also lead patients to defer a professional medical consultation which, in turn, may lead to more severe disease, drug dependence, and misuse. ${ }^{15,18}$ From a public health perspective, a critical issue is how to inform and educate patients to both take responsibility for their own health care (which may involve self-medication eg, of analgesics) whilst understanding when they should not self-medicate with drugs such as antibiotics. ${ }^{19}$

\section{Antimicrobial resistance}

Globally, AMR is developing at great speed, threatening the efficacy of antibiotics, and endangering millions with life-threatening infectious diseases (including pneumonia, tuberculosis, malaria, gonorrhea, and foodborne diseases) that were once easily treatable. ${ }^{20} \mathrm{~A}$ combination of biotic, behavioral, monetary, ecological, and community factors has led to the present situation of AMR being described as catastrophic and, as such, it is high on the global political health care agenda. ${ }^{17,21,22}$ Indeed, the threat of AMR is so calamitous that microbiologists, epidemiologists, and doctors are positing that we are moving into a "postantibiotic" period ${ }^{23}$ in which humans may well be in as much danger of microbial infections as they were before penicillin was discovered. ${ }^{24}$ In 2014, the WHO wrote a serious cautionary letter, noting that "the world is headed for a post-antibiotic era, in which common infections and minor injuries, which have been treatable for decades, can once again kill." 25

These threats are found in both low and high resource settings. For example, Professor Dame Sally Davies, the Chief Medical Officer for England, described AMR as both a "catastrophic threat" 26 and an "apocalyptical threat" which does not follow geopolitical borders. ${ }^{12,28}$ Tuberculosis, pneumonia, and gastroenteritis were three major killer diseases in the USA before the era of penicillins, responsible for $30 \%$ of all deaths and (because of AMR) these infections are reappearing with potentially devastating consequences. ${ }^{29}$ "Methicillin-Resistant Staphylococcus aureus (MRSA)", alone kills more people globally every year than many other diseases in combination..$^{30}$ Of all bacteria, $S$. aureus has the largest potential to cause widespread microbial infections ${ }^{31}$ and, as an opportunistic pathogenic microorganism causes superficial skin and soft tissue invasive infections including pneumonia, bloodstream infections, bone, and joint infections. ${ }^{32-34}$ S. aureus and MRSA are "one of the most frequent reasons for health care-associated infections". ${ }^{35}$ Asia, as the most populous continent, has the highest "rates of health care-associated methicillin-resistant Staphylococcus aureus and community-associated methicillin-resistant Staphylococcus aureus" ${ }^{\$ 6,37}$ and in many Asian hospitals MRSA is becoming multidrug-resistant (MDR). ${ }^{38-40}$

In the US, the Center for Disease Control and Prevention (CDC) documented the first "18 drug-resistant microorganisms" as threats to the public health care system, categorized based on their potential to cause lifethreatening disease at three levels: "urgent, serious, and concerning." $" 41$ Threats allocated to the "urgent and serious" types necessitate more intensive care and precautionary measures. The CDC line of action is customized based on the epidemiology of the infectious microbial diseases, finding loopholes that might promote resistance and preventing resistance.

\section{AMR in Malaysia}

In Malaysia, Ampicillin is widely used to treat Escherichia coli induced urinary tract infection, and Erythromycin is widely used to treat Streptococcus pneumoniae induced pneumonia but at least $50 \%$ of $E$. coli infections and $25 \%$ of $S$. pneumoniae infections are resistant. ${ }^{42}$ Furthermore, in 2014 the hospital variety of S. pneumonia shows an increase resistance up to $35.7 \%$ from an earlier year to Erythromycin and Enterococcus faecium 
an increase of $9.3 \%$ to Vancomycin. ${ }^{42}$ A principal source of amplified AMR is the "overuse or inappropriate use of antibiotics that will lead to difficulties in treating common bacterial infections and increased health care costs." ${ }^{, 43}$ In Malaysia, the use of antimicrobials, both prescribed and purchased over-the-counter has increased by $16 \%$ annually, although it has decreased in some neighboring countries. $^{44,45}$ In 2015, 39 hospital microbiology laboratories were tracked by the National Surveillance of Antibiotic Resistance group which reported that almost every variety of pathogenic microorganisms was resistant to some extent and that the gene mcr- 1 had been isolated in a Malaysian patient. ${ }^{46}$ This new gene can make bacteria resistant to colistin (a last-resort drug for some MDR infections) was first reported in China in November 2015 and in the United States in May 2016. ${ }^{47}$ The high economic growth in Southeast Asia (including Malaysia) has led to increased consumption of antimicrobials, especially with over the counter antibiotics, and it is anticipated that the region will see more widespread AMR emergence and spread. $^{48}$

\section{Antibiotic resistance and health care costs}

Although increasing numbers of microbial infections are resistant to antimicrobial drugs, ${ }^{49}$ prior to 2000 , no different types of antibiotics had been released for public sale for over 25 years and since then, only three new types of antibiotics for human treatment purpose have been made available for public purchase $\mathrm{e}^{50,51}$ This lack of new antibiotics has come about because of increasing competition between pharmaceutical companies, lowering profit margins, and stringent policy issues. ${ }^{52-59}$ This increase in AMR comes at a high financial cost, with treatment costs for patients infected with antibiotic-resistant microorganisms being US\$6,000-30,000 higher than those infected with antimicrobial-susceptible organisms. ${ }^{60,61}$ To highlight the scale of AMR, a recent US study reported that resistant microorganisms infected around 2,000,000 patients, causing 23,000 deaths, and increasing health care costs around US $\$ 55-70$ billion annually. ${ }^{62}$ Specifically, "extendedspectrum $\beta$-lactamase Enterobacteriaceae, MRSA, vancomycin-resistant Enterococcus (VSE), MDR Acinetobacter or Pseudomonasspp. are reported by many studies to increase treatment costs by US\$7,212-98,575 per patient". ${ }^{63-71}$

\section{Self-medication reports and hazards}

One recent systematic review reported that SMA was common among people in the Middle East and contributed to using antibiotics wrongly. ${ }^{2}$ This study also revealed that better, more widespread health education by health care professionals and strict policy implementation regarding "over the counter sales of antibiotics" would help reduce SMA. ${ }^{2}$ Similarly, an Indian study reported an urgent need to develop health education programs for the public regarding self-medication, especially of antimicrobials, to improve knowledge, promote the rational use of drugs and help prevent adverse effects, including AMR. ${ }^{18}$ Cultural health beliefs and the level of education both greatly affect the nature and type of self-medication. For example, a Nigerian study reported that " $41.9 \%, 9.1 \%, 4.0 \%$, $3.5 \%$, and $1.3 \%$ " of pregnant women self-medicate for "fever/pain; herbs and other drugs; sedatives; alcohol; and kola nuts" respectively to protect themselves from "witches and witchcrafts, abortion, bleeding; insomnia, fever, vomiting, and infections." statistically "significant $(p=0.001)$ " differences between pregnant educated and uneducated women regarding the self-medication of analgesics and antibiotics, with the former self-medicating much less. ${ }^{72}$

A study in Saudi Arabia found a 78.7\% self-medication rate of antimicrobials, with amoxicillin, ciprofloxacin, and penicillin being the antibiotics most self-consumed. ${ }^{73}$ One recent cross-sectional study in Pakistan reported a selfmedication rate for antimicrobials of $15.2 \%$ which was considered a huge public health issue. ${ }^{74}$ Additional studies in Pakistan found that self-prescribed antibiotics were principally taken for "colds, coughs, diarrhea, flu, fever, and sore throats" $" 75,76$ and most of them were university students. ${ }^{77}$ These trends are replicated throughout the world, for example, in Mongolia (71\%), ${ }^{3}$ Spain (54.1\%), Zambia (97\%), ${ }^{79}$ Indonesia (64\%), ${ }^{80}$ Pakistan, $(81.25 \%),{ }^{81}$ India $(39.3 \%),{ }^{82}$ Peru $(65.4 \%),{ }^{83}$ Malaysia $(9 \%),{ }^{84}$ Bangladesh (26.69\%), ${ }^{85}$ and Haiti (45.5\%). ${ }^{86}$ Globally, selfmedication with antibiotics is a huge public health issue because of ever-increasing antibiotic-resistance. ${ }^{87-93}$

Whilst the practice of SMA and other drugs is more common among the public than more educated people and health professionals, it is still common among health care professionals and university students from Malaysia and other countries. $^{94-97}$ This research was specifically concentrated among students of the Universiti Pertahanan Nasional Malaysia [(UPNM) National Defence 
University of Malaysia], with participants being military medical and non-medical students, mainly cadet officers. Whilst this was an opportunistic sample as the lead researcher works at the University, no research had been carried out on military students before.

\section{Materials and methods}

\section{Study design}

This was a cross-sectional study. This article reports on findings from one part of the study.

\section{Study population}

The study population comprised medical and non-medical students of the National Defence University of Malaysia [UPNM].

\section{Study period}

Data were collected between 1 January and 30 April 2018.

\section{Sampling method and Sample size}

UPNM is a military University, most students are cadet officers, although there are some territorial and civil students. Students are extensively occupied with mandatory military training included within each program and access to students for research is difficult, The researchers used random sampling for the non-medical students from the faculties of i. Defence Studies and Management (FDSM), ii. Engineering (FE), iii. Defence Sciences and Technology (FDST), and iv. Language Center (LC). In the 2017-2018 academic year, there was a total of 1,746 student in these faculties and center. The Raosoft Sample Size Calculator was used to calculate the sample size. ${ }^{98}$ The calculated sample size was $316+32(10 \%$ non-response $)=348$ " (Error Margin $=5 \%$, Confidence Level $=95 \%$, Response distribution $=50 \%$, and Total Sample size $=1746$ )". ${ }^{98}$ All 1,746 students were invited to participate in the study and, from these, 445 students volunteered and consented to participate through completion of a survey questionnaire. The population size of medical students was small $(N=230)$, as only 50 students are admitted each year, and universal sampling was used for this group.

\section{Techniques of data collection}

Data were collected using a previously validated instrument regarding antibiotic use with permission (Appendix I). ${ }^{99}$ All research participants were given details about the objectives of the research, and (especially for non-medical research participants) information clarifying which medications were antibiotics. The self-administered questionnaire comprised three sections:

- Section A - socio-demographic data, including age, gender, place, and year of birth and program;

- Section B - Self-medication behaviors;

- Section C - Knowledge about antibiotics.

Prior to the full survey, the questionnaire was pre-tested and validated in the local context involving 45 (5 from each year) medical $(5 \times 5=25)$ and non-medical $(5 \times 4=20)$ students. These students did not participate in the subsequent primary study. The questionnaire sections demonstrated acceptable values, with a range between 0.672 and 0.882 , which indicated that both instruments possessed good internal consistency and reliability. Convergent validity was shown by the significant correlations between the items of each section and the total mean in each part $(r \mathrm{~s}=0.332-0.718 ; p=0.05)$. The study pretested result corresponds with earlier studies. ${ }^{100,101}$

\section{Data analysis and interpretation}

The data collected from this study were entered and analyzed using SPSS Version 21 (IBM Corporation, Armonk, NY, USA). The socio-demographic characteristics of the participants were described using frequency and percentages, since they are categorical variables, and compared between medical and non-medical students using the Chisquare test. The use and frequencies of SMA; reasons, diseases, basis and when to stop antibiotics during SMA and the practices and use of antibiotics during SMA were also described using frequency and percentages and compared between medical and non-medical students using Chi-square test. In the logistic regression, forward and backward LR test were used to select the variables to be included in the final model of multiple logistic regression. Each variable was also entered back into the model one by one and removed again if it was not significant, until the final model was achieved. The final model was checked to ensure that the model fitness is good. Some missing values were noted during data analysis as not all participants answered all questions fully. These were automatically excluded from the analysis as per the default setting of analysis using SPSS. The significance level was set at $\alpha=0.05$. 
Table I Socio-demographic characteristics of medical and non-medical students $(n=649)$

\begin{tabular}{|c|c|c|c|c|}
\hline Variables & Total $^{\mathrm{a}}$ No. (\%) & Medical No. (\%) & Non-medical $^{\text {b }}$ No. (\%) & $p$-value ${ }^{c}$ \\
\hline Gender: & & No. (\%) & No. (\%) & 0.298 \\
\hline Male & $314(48.5)$ & $105(5 \mid .5)$ & $209(47.1)$ & \\
\hline Female & $334(5 \mid .5)$ & $99(48.5)$ & $235(52.9)$ & \\
\hline Marital status: & & & & 0.023 \\
\hline Single & $636(98.3)$ & $204(100.0)$ & $432(97.5)$ & \\
\hline Married & II (I.7) & $0(0)$ & II (2.5) & \\
\hline Family in health care: & & & & 0.001 \\
\hline Yes & $124(19.2)$ & $54(26.5)$ & 70 (I5.9) & \\
\hline No & $521(80.8)$ & $150(73.5)$ & $37 \mid(84.1)$ & \\
\hline Year of study: & & & & $<0.001$ \\
\hline 1 & $272(42.1)$ & $56(27.5)$ & $217(48.8)$ & \\
\hline 2 & $146(22.5)$ & $38(18.6)$ & $108(24.3)$ & \\
\hline 3 & 157 (24.2) & $39(19.1)$ & $118(26.5)$ & \\
\hline 4 & $35(5.4)$ & $33(16.2)$ & $2(0.4)$ & \\
\hline 5 & $38(5.9)$ & $38(18.6)$ & $0(0)$ & \\
\hline Examination grade: & & & & $<0.001$ \\
\hline I or $\mathrm{A}$ & $98(19.8)$ & II (5.4) & $87(29.9)$ & \\
\hline 2 or $B$ & $246(49.7)$ & $107(52.5)$ & $139(47.8)$ & \\
\hline 3 or $C$ & 138 (27.9) & $86(42.2)$ & $52(17.9)$ & \\
\hline 4 & $13(2.6)$ & $0(0)$ & $13(4.5)$ & \\
\hline Admission type: & & & & $<0.001$ \\
\hline Cadet Officer & $117(18.5)$ & $110(53.9)$ & $7(1.6)$ & \\
\hline Territorial Army & $37 \mid(58.7)$ & $26(12.7)$ & $345(80.6)$ & \\
\hline Civil & $144(22.8)$ & $68(33.3)$ & $76(17.8)$ & \\
\hline Allowance: & & & & $<0.001$ \\
\hline$<$ RM500 & $327(65.0)$ & $73(35.8)$ & $254(84.9)$ & \\
\hline RM500-RMI,000 & $52(10.3)$ & $10(4.9)$ & $42(14.0)$ & \\
\hline RMI,00I-RM2,000 & $105(20.9)$ & $102(50.0)$ & $3(1.0)$ & \\
\hline$>\mathrm{RM} 2,000$ & $6(1.2)$ & $6(2.9)$ & $0(0)$ & \\
\hline Others & $13(2.6)$ & $13(6.4)$ & $0(0)$ & \\
\hline Health insurance: & & & & $<0.001$ \\
\hline None & $110(30.0)$ & $80(39.2)$ & $30(18.4)$ & \\
\hline Free medical care & $84(22.9)$ & $44(21.6)$ & $40(24.5)$ & \\
\hline Various type & $173(47.1)$ & $80(39.2)$ & $93(57.1)$ & \\
\hline
\end{tabular}

${ }^{a}$ With some missing values. ${ }^{b} \mathrm{FDSM}, \mathrm{FE}, \mathrm{FDST}$, and LC. ${ }^{\mathrm{c} C h i-s q u a r e}$ test between medical and non-medical faculties $\left({ }^{\mathrm{b}}\right)$.

Abbreviations: FDSM, Faculty of Defence Studies and Management; FE, Faculty of Engineering; FDST, Faculty of Defence Sciences and Technology; LC, Language Center; RM, Malaysian Ringgit. 


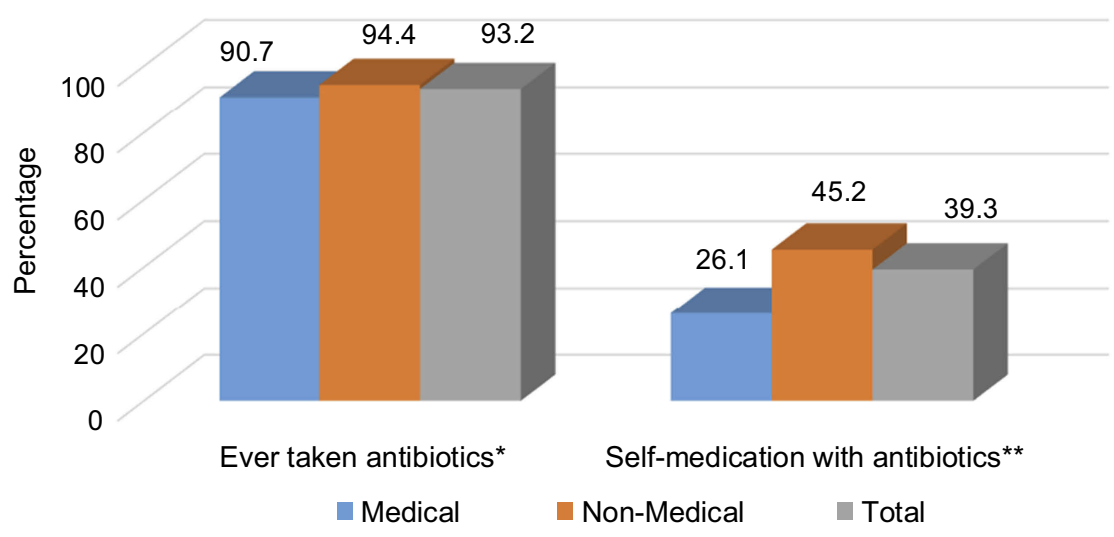

Figure I Percentages use of antibiotics among medical $(n=204)$ and non-medical $(n=445)$ students (Total $n=649)$. *No significant difference between medical and nonmedical students, Chi-square $p=0.082$. **Significant difference between medical and non-medical students, Chi-square $p<0.001$.

\section{Ethical considerations}

This research study was approved by the Institutional Ethical Clearance Committee, Centre for Research and Innovation Management, UPNM, Kem Sungai Besi, 57,000 Kuala Lumpur, Malaysia, Code of Research: UPNM/2017/SF/SKK/03, Memo No: UPNM (PPPI) 16.01/06/023 (2), 23 August 2017. The study population was informed about the objectives and process of the study that the data gathered would be anonymized and used for publication, and that study participation was entirely voluntary with no penalty should they choose not to participate. Written consent was obtained before the questionnaires were distributed.

\section{Reasons for focusing defence university}

The Principal Investigator works in the National Defence University of Malaysia and therefore had access to the study participants, which are a unique group in Malaysia. This leads to some limitations of the study as it is an opportunistic sample but it was not possible to carry out a multi-center study within the resource constraints.

\section{Results}

\section{Sociodemographic variables between medical and non-medical respondents}

The distribution of sociodemographic characteristics of the participants' is set out in Table 1, including the comparison between medical and non-medical students (using Chi-square test). Respondents included slightly more females $(\mathrm{n}=334 ; 51.5 \%)$, the majority were unmarried $(\mathrm{n}=636 ; 98.3 \%)$ and did not have any family members working in health care services $(\mathrm{n}=521 ; 80.8 \%)$. Most participants described themselves as Malay in terms of race $(563,88.52 \%)$, the others being Chinese, Indian, and others. The median age of the participants was 21 years old with an inter-quartile range of 2 . The independent $t$-test results indicated that the medical students were slightly (but significantly) older $(n=204 ;$ mean $=21.8$ years old; standard deviation $[\mathrm{SD}]=1.46)$ than the nonmedical students $(\mathrm{n}=445$; mean $=21.4$ years old; $\mathrm{SD}=1.18$ ) with a $p$-value of $<0.001$. More than half of the participants received a monthly allowance of less than RM500 $(\mathrm{n}=327 ; 65.0 \%)$. Table 1 highlights that the sociodemographic characteristics between medical and nonmedical students showed significant differences $(p<0.05)$, except for gender $(p=0.298)$. Medical students had a higher percentage of participants with family members working in health care services; were in Year 4 and 5 of their studies; had obtained Grades B and C in their examinations; were admitted as Cadet Officers; had a higher allowance and free medical care compared to those from non-medical faculties.

\section{Students' self-medication with antibiotics within the last year}

Most respondents had taken antibiotics $(\mathrm{n}=605 ; 93.2 \%)$ in the last year, and 39.3\% ( $\mathrm{n}=239)$ had practiced SMA (Figure 1). Antimicrobials were principally consumed for a runny nose, nasal congestion, cough, sore throat, fever, aches and pains, vomiting, diarrhea, and skin wounds (Table 2). The Chi-square test showed no significant difference between the medical or non-medical students regarding whether they had ever taken antibiotics $(p=0.082)$ but a significantly higher percentage of nonmedical students had self-medicated with antibiotics compared to medical students $(p<0.001)$. Figure 2 shows the 
Table 2 Reasons, diseases, basis and when to stop antibiotics during self-medication of antibiotics (SMA) among medical and nonmedical students $(n=239)$

\begin{tabular}{|c|c|c|c|c|}
\hline Variables & Total ${ }^{a}$ No. (\%) & Medical No. (\%) & Non-medical ${ }^{b}$ No. (\%) & $p$-Value ${ }^{c}$ \\
\hline Reasons for SMA: & & & & 0.005 \\
\hline Cost saving & $81(35.7)$ & $18(37.5)$ & $63(35.2)$ & \\
\hline Convenience & $96(42.3)$ & $20(4 \mid .7)$ & $76(42.5)$ & \\
\hline Lack of trust in prescribing doctors & $16(7.0)$ & $0(0)$ & $16(8.9)$ & \\
\hline Other reasons & $19(8.4)$ & $2(4.2)$ & $17(9.5)$ & \\
\hline Multiple answers ${ }^{d}$ & $15(6.6)$ & $8(16.7)$ & $7(3.9)$ & \\
\hline Diseases for SMA: & & & & 0.052 \\
\hline Running nose & $5(2.3)$ & $0(0)$ & $5(2.9)$ & \\
\hline Nasal congestion & $5(2.3)$ & $\mathrm{I}(2.1)$ & $4(2.3)$ & \\
\hline Cough & $9(4.1)$ & $3(6.3)$ & $6(3.5)$ & \\
\hline Sore throat & $8(3.6)$ & I (2.I) & $7(4.1)$ & \\
\hline Fever & $56(25.5)$ & $8(16.7)$ & $48(27.9)$ & \\
\hline Ache and pain & $9(4.1)$ & I (2.I) & $8(4.7)$ & \\
\hline Vomiting & $4(1.8)$ & $0(0)$ & $4(2.3)$ & \\
\hline Diarrhea & $3(1.4)$ & $2(4.2)$ & $\mathrm{I}(0.6)$ & \\
\hline Skin wounds & $8(3.6)$ & $0(0)$ & $8(4.7)$ & \\
\hline Other diseases & $7(4.1)$ & $0(0)$ & $7(4.1)$ & \\
\hline Multiple answers ${ }^{\mathrm{d}}$ & $106(48.2)$ & $32(66.7)$ & $74(43.0)$ & \\
\hline Basis for SMA: & & & & 0.428 \\
\hline Recommendation by pharmacist & $58(24.5)$ & $7(14.6)$ & $51(27.0)$ & \\
\hline Opinion by family members & $10(4.2)$ & $\mathrm{I}(2.1)$ & $9(4.8)$ & \\
\hline Opinion by friends & $2(0.8)$ & $I(2.1)$ & $\mathrm{I}(0.5)$ & \\
\hline Own experience & II (4.6) & $2(4.2)$ & $9(4.8)$ & \\
\hline Previous doctor's prescription & $85(35.9)$ & $19(39.6)$ & $66(34.9)$ & \\
\hline Advertisement & I $(0.4)$ & $0(0)$ & I $(0.5)$ & \\
\hline Multiple answers $^{d}$ & $70(29.5)$ & $18(37.5)$ & $52(27.5)$ & \\
\hline When to stop antibiotics: & & & & 0.684 \\
\hline After a few days, regardless of the outcome & $20(8.7)$ & $5(10.6)$ & $15(8.2)$ & \\
\hline After symptoms disappeared & $72(3 \mid .2)$ & $17(36.2)$ & $55(29.9)$ & \\
\hline Few days after recovery & $27(11.7)$ & $2(4.3)$ & $25(13.6)$ & \\
\hline After antibiotics ran out & $37(16.0)$ & $8(17.0)$ & $29(15.8)$ & \\
\hline After completed antibiotic course & $14(6.1)$ & $4(8.5)$ & $10(5.4)$ & \\
\hline After consulting doctor/pharmacist & $12(5.2)$ & $2(4.3)$ & $10(5.4)$ & \\
\hline Others & $2(0.9)$ & $0(0)$ & $2(1 . I)$ & \\
\hline Multiple answers $^{d}$ & $47(20.3)$ & $9(19.1)$ & $38(20.7)$ & \\
\hline
\end{tabular}

Notes: ${ }^{a}$ With some missing values. ${ }^{b}$ Faculty of Management, Engineering, Science and Language. ${ }^{\mathrm{c}}$ Chi-square test between medical and non-medical students ( ${ }^{\mathrm{b}}$ ) (Expected

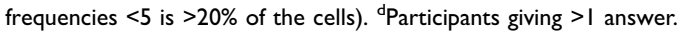

frequency of SMA and illustrates that the medical students have a significantly lower SMA than the non-medical students with a Chi-square of $p<0.001$. The other details regarding SMA are shown in Tables 2-4.

Table 2 shows the significant differences regarding reasons for SMA between medical and non-medical students. Most practiced SMA because of its convenience $(n=96 ; 42.3 \%)$ [Medical $(n=20 ; 41.7 \%)$ and non-medical students $(n=76 ; 42.5 \%)$ ] or cost savings [Medical $(n=18$; $37.5 \%)$ and non-medical students $(n=63 ; 35.2 \%)$, though not much difference was seen between both groups. Differences were found relating to lack of trust in the prescribing doctors as one of the reasons for SMA, where none of the medical students had lack of trust in their prescribing doctors as compared to non-medical students $(n=16 ; 8.9 \%)$. Furthermore, more non-medical students gave "other reasons" as their reason $(n=17 ; 9.5 \%)$ while more medical students gave multiple answers to these questions $(n=8 ; 16.7 \%)$. However, there was no significant difference between the medical and non- 


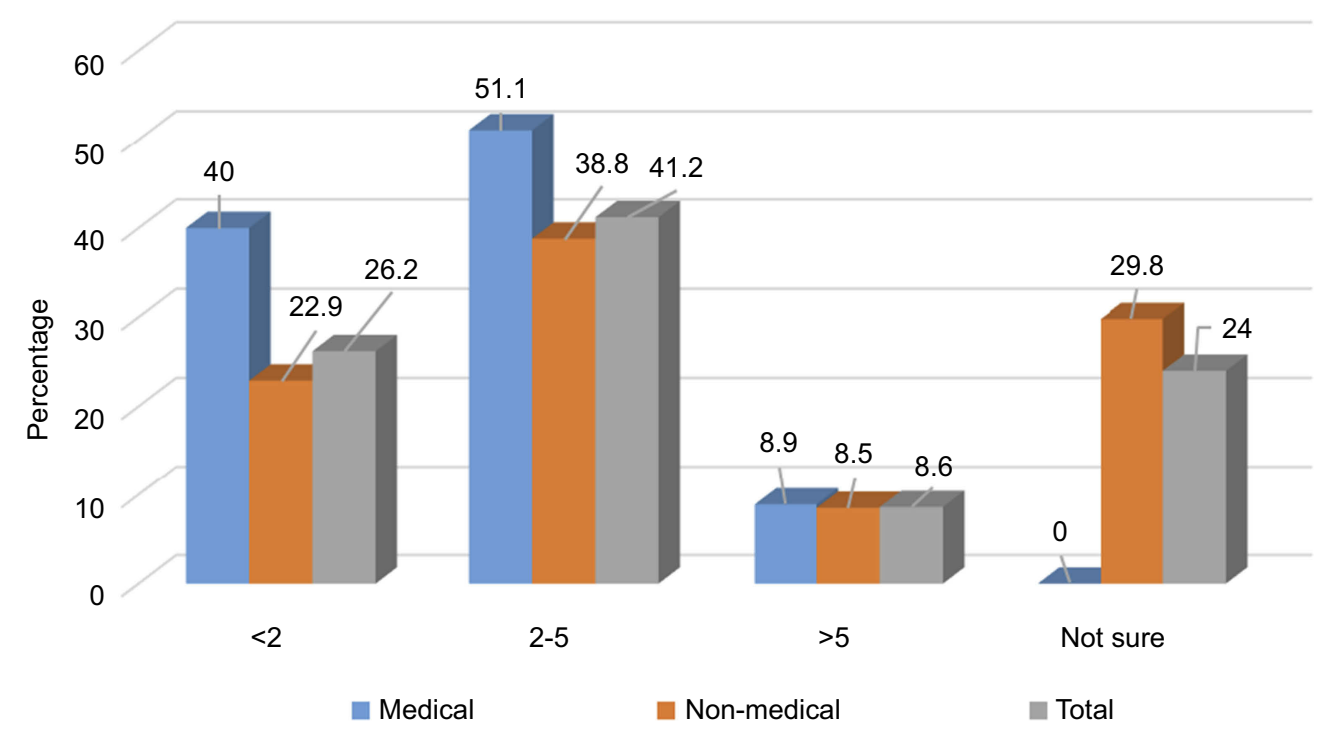

Figure 2 Percentages of frequencies of self-medication of antibiotics (SMA) among medical $(n=49)$ and non-medical $(n=190)$ students (Total $n=239)$. *Significant difference between medical and non-medical students, Chi-square $p<0.001$.

medical students regarding the diseases, the basis for SMA, nor the reasons they stopped antibiotics during SMA ( $p=0.052,0.428$ and 0.684 , respectively). Amongst all respondents, the main disease or condition for SMA was due to fever ( $\mathrm{n}=56 ; 25.5 \%$ ); SMA was mainly practiced based on a previous doctor's prescription $(n=85$; $35.9 \%$ ) and the majority stopped the antibiotics once their symptoms disappeared $(\mathrm{n}=72 ; 31.2 \%)$. No medical students cited a lack of trust in prescribing doctors, whereas 16 (8.9\%) non-medical students stated that was a reason for SMA (Chi-square $p=0.005$ ).

Table 3 shows that most respondents described the main considerations in choosing antibiotics during SMA as the type of antibiotics $(\mathrm{n}=88 ; 37.1 \%)$; obtaining their antibiotics from community pharmacies $(\mathrm{n}=155 ; 66.0 \%)$; knowing the dosage after consulting a doctor $(n=65$; $27.8 \%$ ) and taking only one type of antibiotic during an illness $(\mathrm{n}=98 ; 55.1 \%)$. There was no significant difference between medical and non-medical students regarding the dosage and the maximum number of antibiotics taken during an illness. However, significant differences were observed between the two groups regarding the consideration for SMA and where they obtained the antibiotics for SMA. A higher percentage of medical students gave either multiple answers or the brand and price of the antibiotics as their main consideration compared to non-medical students, who were more concerned about the type or an adverse reaction from the antibiotics.
The practices regarding the use of antibiotics during SMA are shown in Table 4. Very few participants "always" change dosage or switch antibiotics during SMA $(\mathrm{n}=19 ; 8.1 \%$ and $\mathrm{n}=19 ; 8.2 \%$, respectively), though quite a number "sometimes" did that $(n=97$; $41.3 \%$ and $\mathrm{n}=82 ; 35.3 \%$, respectively). The majority did not fully understand the instruction on the antibiotic package however $(n=136,60.2 \%)$, were somewhat concerned about taking counterfeit antibiotics $(\mathrm{n}=108$; 46.4\%), did not experience any adverse effects during SMA ( $\mathrm{n}=164 ; 71.3 \%$ ), thought that SMA was an acceptable practice $(\mathrm{n}=144 ; 61.3 \%)$ but were not sure whether they could successfully treat the infection on their own $(n=151 ; 64.3 \%)$. Less than half of the participants had taken the same antibiotics with different names during a course of antibiotics $(n=93 ; 40.1 \%)$.

The comparison between medical and non-medical students regarding the use of antibiotics during SMA (Table 4) showed a significant difference for understanding the instruction on the antibiotics package, where as might be expected, a higher percentage of medical students understood the instruction fully $(p=0.015)$. In addition, a higher percentage of medical students switched antibiotics during SMA $(p=0.004)$ and did not think that they could successfully treat themselves $(p=0.011)$. A higher percentage of nonmedical students were more concerned about taking counterfeit antibiotics $(p=0.011)$ and thinking that SMA is a good or acceptable practice $(p=0.002)$. 
Table 3 Practices regarding self-medication of antibiotics (SMA) among medical and non-medical students $(n=239)$

\begin{tabular}{|c|c|c|c|c|}
\hline Variables & Total $^{\mathrm{a}}$ No. (\%) & Medical No. (\%) & Non-medical ${ }^{\mathbf{b}}$ No. (\%) & $p$-Value ${ }^{c}$ \\
\hline Consideration for SMA: & & & & 0.007 \\
\hline Type of antibiotics (AB) & $88(37.1)$ & $14(29.2)$ & $74(39.2)$ & \\
\hline Brand of $A B$ & II (4.6) & $5(10.4)$ & $6(3.2)$ & \\
\hline Price of $A B$ & $9(3.8)$ & $3(6.3)$ & $6(3.2)$ & \\
\hline Indication of use & $39(16.5)$ & $6(12.5)$ & $33(17.5)$ & \\
\hline Adverse reaction & $26(11.0)$ & $\mathrm{I}(2 . \mathrm{I})$ & $25(13.2)$ & \\
\hline Other considerations & $5(2.1)$ & $0(0)$ & $5(2.6)$ & \\
\hline Multiple answers ${ }^{\mathrm{d}}$ & $59(24.9)$ & $19(39.6)$ & $40(21.2)$ & \\
\hline Place to get $A B$ : & & & & 0.001 \\
\hline Community pharmacies & $155(66.0)$ & $20(41.7)$ & $135(72.2)$ & \\
\hline TCM practitioners & $7(3.0)$ & $\mathrm{I}(2.1)$ & $6(3.2)$ & \\
\hline Leftovers & $28(11.9)$ & $12(25.0)$ & $16(8.6)$ & \\
\hline Online shopping/E-Pharmacies & $2(0.9)$ & $0(0)$ & $2(1.1)$ & \\
\hline Other places & $16(6.8)$ & $5(10.4)$ & II (5.9) & \\
\hline Multiple answers $^{\mathrm{d}}$ & $27(11.5)$ & $10(20.8)$ & $17(9.1)$ & \\
\hline How to know the dosage: & & & & 0.136 \\
\hline Checking inside package & $39(16.7)$ & $10(20.8)$ & $29(15.6)$ & \\
\hline Consulting a doctor & $65(27.8)$ & II (22.9) & $54(29.0)$ & \\
\hline Consulting a pharmacist & $25(10.7)$ & $2(4.2)$ & $23(12.4)$ & \\
\hline Consulting family member/friend & $4(1.7)$ & $I(2.1)$ & $3(1.6)$ & \\
\hline From newspapers/magazines/books/TV programs & I (0.4) & $0(0)$ & I (0.5) & \\
\hline From internet & $2(0.9)$ & $2(4.2)$ & $0(0)$ & \\
\hline Previous experience & $3(1.3)$ & $I(2.1)$ & $2(1.1)$ & \\
\hline Guessing the dose & I (0.4) & $0(0)$ & $\mathrm{I}(0.5)$ & \\
\hline Multiple answers $^{\mathrm{d}}$ & $94(40.2)$ & $21(43.8)$ & $73(39.2)$ & \\
\hline Max. no. of $A B$ taken during an illness: & & & & 0.606 \\
\hline I & $98(55.1)$ & $26(59.1)$ & $72(53.7)$ & \\
\hline 2 & $62(34.8)$ & $15(34.1)$ & $47(35.1)$ & \\
\hline$>2$ & $13(7.3)$ & $3(6.8)$ & $10(7.5)$ & \\
\hline Not sure & $5(2.8)$ & $0(0)$ & $5(3.7)$ & \\
\hline
\end{tabular}

Notes: ${ }^{a}$ With some missing values. ${ }^{b}$ Faculty of Management, Engineering, Science and Language. ${ }^{c}$ Chi-square test between medical and non-medical students ( $\left.{ }^{b}\right)$ (Expected

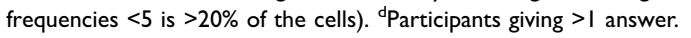

Abbreviation: TCM, Traditional Chinese Medicine.

\section{Self-medication with antibiotics association with knowledge}

Scores from the knowledge section were collated to calculate total knowledge scores, which were then compared between the medical and non-medical students. The mean total scores of the participants were 5.4 $(\mathrm{SD}=1.49)$ with a range of between 2 and 9 out of a possible maximum score of 9 . The result of comparison using MANCOVA (by taking into consideration the possible confounding effect of age, gender, year of study, examination grade and SMA practice) is shown in Figure 3. As might be expected, the results showed independently significantly higher total scores of knowledge about antibiotics among medical students (estimated marginal mean $(\mathrm{EMM})=5.9 ; 95 \%$ confidence interval $(\mathrm{CI})=5.57,6.18)$ compared to nonmedical students $(\mathrm{EMM}=4.7 ; 95 \% \mathrm{CI}=4.44,4.95)$ with the $p$-value of 0.002 .

\section{Factors associated with self-medication with antibiotics}

Simple logistic regression was carried out, followed by multiple logistic regression to identify the independently associated factors for SMA. An OR of more than 1 means there is a higher risk of practicing SMA whilst an OR of less than 1 means there is a lower risk of practicing SMA. 
Table 4 Practices regarding the use of antibiotics during self-medication of antibiotics (SMA) among medical and non-medical students $(n=239)$

\begin{tabular}{|c|c|c|c|c|}
\hline Variables & Total ${ }^{\mathrm{a}}$ No. (\%) & Medical No. (\%) & Non-medical' ${ }^{\mathrm{b}}$ No. (\%) & $p$-Value ${ }^{c}$ \\
\hline $\begin{array}{l}\text { Understand the instruction on package: } \\
\text { Fully understood } \\
\text { Partly or did not understand }\end{array}$ & $\begin{array}{l}90(39.8) \\
136(60.2)\end{array}$ & $\begin{array}{l}26(55.3) \\
21(44.7)\end{array}$ & $\begin{array}{l}64(35.8) \\
115(64.2)\end{array}$ & 0.015 \\
\hline $\begin{array}{l}\text { Change dosage during SMA: } \\
\text { Yes, always } \\
\text { Yes, sometimes } \\
\text { Never }\end{array}$ & $\begin{array}{l}19(8.1) \\
97(41.3) \\
119(50.6)\end{array}$ & $\begin{array}{l}6(12.5) \\
15(31.3) \\
27(56.3)\end{array}$ & $\begin{array}{l}13(7.0) \\
82(43.9) \\
92(49.2)\end{array}$ & 0.192 \\
\hline $\begin{array}{l}\text { Switch antibiotics }(A B) \text { during SMA: } \\
\text { Yes, always } \\
\text { Yes, sometimes } \\
\text { Never }\end{array}$ & $\begin{array}{l}19(8.2) \\
82(35.3) \\
\mid 31(56.5)\end{array}$ & $\begin{array}{l}9(18.8) \\
11(22.9) \\
28(58.3)\end{array}$ & $\begin{array}{l}10(5.4) \\
71(38.6) \\
103(56.0)\end{array}$ & 0.004 \\
\hline $\begin{array}{l}\text { Concern about taking counterfeit AB: } \\
\text { Yes, very much } \\
\text { Yes, somewhat } \\
\text { No }\end{array}$ & $\begin{array}{l}59(25.3) \\
108(46.4) \\
66(28.3)\end{array}$ & $\begin{array}{l}14(29.8) \\
13(27.7) \\
20(42.6)\end{array}$ & $\begin{array}{l}45(24.2) \\
95(51.1) \\
46(24.7)\end{array}$ & 0.011 \\
\hline $\begin{array}{l}\text { Taken same } A B \text { with different names: } \\
\text { Yes } \\
\text { No }\end{array}$ & $\begin{array}{l}93(40.1) \\
139(59.9)\end{array}$ & $\begin{array}{l}17(37.0) \\
29(63.0)\end{array}$ & $\begin{array}{l}76(40.9) \\
110(59.1)\end{array}$ & 0.629 \\
\hline $\begin{array}{l}\text { Adverse reactions during SMA: } \\
\text { Yes } \\
\text { No }\end{array}$ & $\begin{array}{l}66(28.7) \\
164(7 \mid .3)\end{array}$ & $\begin{array}{l}9(19.1) \\
38(80.9)\end{array}$ & $\begin{array}{l}57(3 \mathrm{I} .1) \\
126(68.0)\end{array}$ & 0.105 \\
\hline $\begin{array}{l}\text { SMA for self-health care: } \\
\text { Good practice } \\
\text { Acceptable practice } \\
\text { Not acceptable practice }\end{array}$ & $\begin{array}{l}65(27.7) \\
144(6 \mid .3) \\
26(11.1)\end{array}$ & $\begin{array}{l}11(23.4) \\
24(51.1) \\
12(25.5)\end{array}$ & $\begin{array}{l}54(28.7) \\
120(63.8) \\
14(7.4)\end{array}$ & 0.002 \\
\hline $\begin{array}{l}\text { Successful treatment by SMA: } \\
\text { Yes, I can } \\
\text { Not sure } \\
\text { No, I cannot }\end{array}$ & $\begin{array}{l}58(24.7) \\
15 \mid(64.3) \\
26(I I . I)\end{array}$ & $\begin{array}{l}10(2 \mathrm{I} .3) \\
26(55.3) \\
\mathrm{II}(23.4)\end{array}$ & $\begin{array}{l}48(25.5) \\
125(66.5) \\
\text { I5 (8.0) }\end{array}$ & 0.011 \\
\hline
\end{tabular}

Notes: ${ }^{a}$ With some missing values. ${ }^{b}$ FDSM, FE, FDST, and LC. ${ }^{c}$ Chi-square test between medical and non-medical students $\left({ }^{b}\right)$.

Simple logistic regression found SMA was significantly associated with year of study, namely less SMA in Year 5 compared to Year $1(\mathrm{OR}=0.084 ; 95 \% \mathrm{CI}$ of $\mathrm{OR}=0.020$, $0.359 ; p=0.001$; ; admission type, namely Territorial Army compared to Cadet Officer (OR=2.423; 95\% CI of $\mathrm{OR}=1.473,3.987 ; p<0.001$ ); medical compared to nonmedical students $(\mathrm{OR}=0.427 ; 95 \%$ CI of $\mathrm{OR}=0.292$, $0.623 ; p<0.001)$; total scores of knowledge $(\mathrm{OR}=0.782$, $95 \% \mathrm{CI}$ of $\mathrm{OR}=0.695,0.881, p<0.001$ ), and monthly allowance, namely between allowance of RM1,001-RM2,000 compared to $<\mathrm{RM} 500$ (OR=0.530; $95 \%$ CI of $\mathrm{OR}=0.315$, $0.890 ; p=0.016)$. After finalizing the multiple logistic regression, only three variables were found to be independently significantly associated with SMA: year of study, medical faculty, and total knowledge scores. Students reporting lower SMA were in Year 5 (compared to Year 1), a medical student (rather than a non-medical student) and having a higher total score of knowledge regarding antibiotics. The full results of the multiple logistic regression are shown in Table 5.

\section{Discussion}

Prescription-only drugs (including antibiotics) are often self-administered as patients feel that they will save money and time, but this can lead to substantial adverse drug reactions, antibiotic resistance, treatment failure, and 


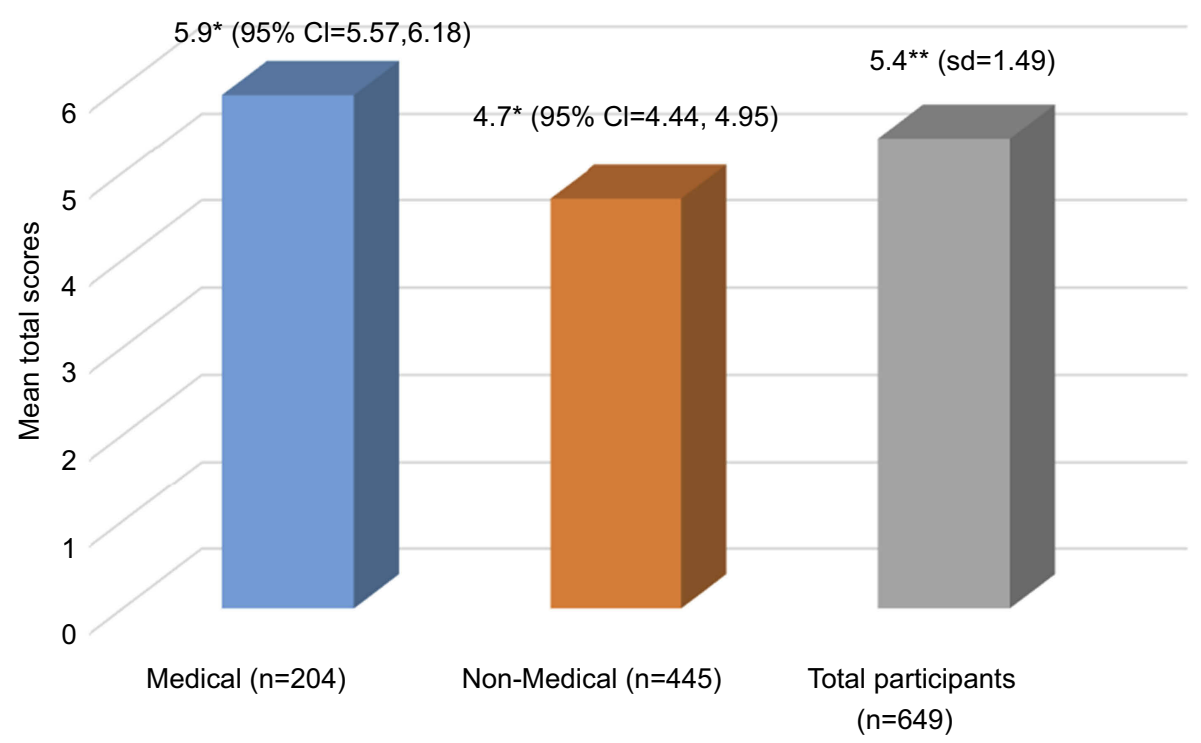

Figure 3 The mean total scores of knowledge about antibiotics among medical and non-medical students. ** Mean; * Estimated marginal mean adjusted by age, gender, year of study, examination grade and practicing self-medication of antibiotics (SMA). A MANCOVA test showed a significant difference between medical and non-medical students adjusted estimated marginal means with $p=0.002$ ).

drug-related toxicity: all of which lead to costs for both individuals and health services ${ }^{18,102}$ With the development of MDR and extremely drug-resistance microbial-strains, treatment options are increasingly limited, and this leads to more visits to doctors; prolonged hospital stays; more expensive proprietary drugs; higher health care costs; poorer quality of life for individuals; increased mortality, and loss of potential work hours. ${ }^{103}$

\section{Study respondents' demographics}

Respondents in the study had similarities with those in other studies involving students. Earlier studies at UPNM reported more male respondents than female. ${ }^{104,105}$ However, although in the current study there were more female respondents than males, there was no statistically significant difference between genders. Most of the current study respondents were unmarried reflecting that cadet officers cannot marry whilst a student, but also that most Malaysian university students are unmarried with the average age of marriage being 26-28 years. ${ }^{106,107}$ Although Malaysia is a multi-ethnic country, Malays are the largest race ${ }^{108}$ and, reflecting that, the respondents were mostly Malay.

\section{Behaviors regarding self-medication with antibiotics}

"The skyrocketing rates of antibiotic prescriptions now suggest that as many as four out of five Americans may

Table 5 Factors associated with self-medication of antibiotics (SMA) using multiple logistic regression $(n=649)$

\begin{tabular}{|l|l|l|l|l|}
\hline Variables & $\mathbf{n}$ & Odds ratio (OR) & 95\% confidence interval of OR & $\mathbf{p}$-Value \\
\hline Year of study: & & & & \\
Year 1* & 272 & $\mathrm{I}$ & - & 1.000 \\
Year 2 & 146 & 0.758 & $(0.484,1.188)$ & 0.227 \\
Year 3 & 157 & 1.097 & $(0.706,1.704)$ & 0.682 \\
Year 4 & 35 & 0.804 & $(0.335,1.930)$ & 0.625 \\
Year 5 & 38 & 0.163 & $(0.036,0.733)$ & 0.018 \\
\hline Students: & & & & 1.000 \\
Medical* & 204 & 1 & - & 0.021 \\
Non-medical & 445 & 0.599 & $(0.387,0.926)$ & 0.023 \\
\hline Total scores of knowledge regarding antibiotics & 649 & 0.863 & $(0.760,0.980)$ & \\
\hline
\end{tabular}

Notes: *Reference group 
be getting antibiotics annually, according to a new study by the CDC. ${ }^{109}$ Internationally between 2000 and 2015 the use of antimicrobials increased to $65 \%{ }^{110}$ which is reflected in the findings of this study. The SMA rate in this study ( $40 \%$ overall) is lower than of Peru $(70 \%)^{83}$ and Asian studies [Pakistan (50.1\%, 58.3\%), India (78.18\%)]. ${ }^{19,97,111}$ However, it is higher than in other Asian studies [Bangladesh (26.69\%, 15.6\%), Bhutan (23.6\%)]. ${ }^{85,112,113}$ In Peru, 70\% of the study respondents treated themselves with antimicrobials two or more times annually. ${ }^{83}$ Similarly, another European study found that respondents reported SMA 2-3 times a year for upper respiratory tract infections. ${ }^{114}$ This study's findings regarding SMA annually were similar. The current study also found that medical students had a lower rate of SMA per year than non-medical students. This could have been anticipated and explained because medical students learn about the correct use of antibiotics and the dangers of misuse during their degree program. Moreover, many of the medical students had family members who were health professionals. A similar positive awareness regarding SMA among medical students was also observed in an earlier study. ${ }^{115}$

Multiple studies report that the high rate of SMA can be explained by poor or lacking drug control measures, regulatory policy, and planning and, whilst antimicrobials are generally prescription-only drugs, patients can buy them over the counter because of the poor practice of regulatory agencies and individuals acquiring antibiotics to sell on the black market. ${ }^{19,116,117,118}$ In addition, the public might have poor knowledge about antimicrobials acquired from "advertisements on television, radio and print media in addition to advice from friends and family." ${ }^{17}$ Cost and convenience are other factors, patients in an "expensive health care system cannot afford to pay the consultation fees of the doctor, (and) going to a doctor's clinic or to the hospital is too much of a hassle." 119 In the light of financial and workforce constraints, governments are increasingly encouraging people to treat minor health ailments themselves and if people do not understand the consequences of SMA they will see taking antibiotics as the same as (for example) taking analgesics. ${ }^{119}$ The health issue reasons for SMA stated by the current study respondents are similar to other Asian studies. ${ }^{85,120}$ The selection of antibiotic based on presenting symptoms was also consistent with earlier studies, principally: pharmacist's recommendation; friends and family members suggestions; previous personal experience and having previously been recommended antibiotics by a registered health professional. ${ }^{2,18,121}$ The source of antibiotics (pharmacists or leftover medicines) also reflected other studies. ${ }^{2}$ Although SMA is considered a potential health hazard especially because of misuse and development of resistant microbes, many respondents reported that they always read and understood medication instructions. Whilst this is a positive finding, almost half of the respondents changed the dosage of antimicrobials (as in another study ${ }^{99}$ ) or changed to another antibiotic because they felt they were not improving, their stock had run out, or they wanted a cheaper alternative. These attitudes reflect an irrational use of antimicrobials which has the potential to promote AMR. Respondents also reported that they suspected they were taking counterfeit drugs and it has been reported that "counterfeit drugs are widely available within the Asia Pacific region, including Malaysia." "22 These study respondents were often taking the same molecule of antibiotic with a different trade name, also found among Chinese University students. ${ }^{99}$ Respondents also frequently stopped taking the antibiotics when their symptom went and they felt better, which conflicts with the WHO campaign regarding AMR. ${ }^{123}$ Penicillin, doxycycline, clarithromycin were the most commonly used antibiotics, and the majority did not report any adverse drug reactions. Multiple studies also report that penicillin is the most commonly abused antibiotic for SMA. ${ }^{20,99}$ However, the most alarming issue highlighted in the study is that, despite antibiotics being prescription-only drugs, most of both groups of respondents think SMA is a good/acceptable practice and one-quarter of them think they can treat and manage infectious diseases themselves. These (relatively privileged) students cite costsaving and convenience as the reasons for SMA. Across low and middle-income countries multiple other studies identify poverty; poor access to health care; scarcity of graduate physicians and other health professionals; a low standard of health care; over the counter availability of antimicrobials, and patients' misapprehensions about medical doctors, as the reasons for SMA. ${ }^{90,124,125}$

\section{Self-medication with antibiotics: association with knowledge}

SMA can lead to adverse drug reactions and interactions, mask signs and symptoms which makes it harder to reach the correct diagnosis, and can promote the development of additional infectious diseases. Additionally, the wrong antibiotic or wrong dosage (often seen in SMA) can lead to microbial resistance, treatment failure, and increased cost. ${ }^{114,126,127}$ 
The results of the current study revealed that medical students had significantly higher total scores of knowledge about antibiotics compared to non-medical students and reported less SMA. This is confirmed by multiple other studies which also report that when medical students have a good knowledge about SMA, subsequently more responsible self-medication practice was observed. ${ }^{128,129,130}$ In order to increase widespread knowledge of the risks of SMA and minimize unnecessary antibiotic use, several studies suggest that national and local educational interventions, antibiotic stewardship, and other activities among all stakeholders regarding antibiotic use are required. ${ }^{131-135}$

\section{Factors associated with self-medication with antibiotics}

One earlier Ethiopian study utilizing bivariate and multivariable analysis found that multiple factors were independently associated with non-prescribed antimicrobial use. ${ }^{136}$ Another study from Serbia using Multivariate logistic regression analysis identified the independent risk factors for self-medication among medical students as possession of home-pharmacy/left-over antibiotics; being female; senior students; lower level of father's education; alcoholic drink intake; a higher Physical Health Questionnaire - 9 score, and minimum physical activity. ${ }^{137}$

In the current study, simple logistic and multiple logistic regression found SMA was significantly associated with several factors. Regarding year of study, it was lower in Year 5 compared to Year 1 students, probably due to the higher level of knowledge about antibiotics and greater maturity of the Year 5 clinical students than their biomedical science peers. The Territorial Army students had a lower reported SMA than the Cadet Officers, which might be explained by the Cadet Officers having much less time available to attend clinics. As expected SMA was lower in medical students than non-medical students; lower with a higher total score of knowledge about antibiotics, and lower in students with a higher monthly allowance (RM1,001-RM2,000 compared to <RM500). The latter can be explained by students with lower incomes looking to save money so buying cheaper over the counter antibiotics than by going to a doctor which costs more.

A recent review revealed substantial overuse and misuse of antibiotics among US physicians. ${ }^{138}$ Moreover, $30 \%$ of these prescriptions were irrational, and $50 \%$ were for acute respiratory diseases, many of which are self-limiting and do not require antimicrobials. ${ }^{139,140}$ This is a global issue. ${ }^{141}$ Resistance of microbes is a natural phenomenon and so even if antibiotic use is rational, AMR will still increase, this is, of course, exacerbated with over-prescribing, and even further by SMA. ${ }^{142}$ Overprescribing is especially predominant (around $40 \%$ being unnecessary) in acute respiratory tract infections. ${ }^{141,143,144,145}$ To improve antibiotics' use and prevent AMR, educational and community awareness-raising interventions are required for all stakeholders including health professionals and consumers. ${ }^{146}$

\section{Limitations of the study}

There are several limitations to this study. First, the study was carried out in a specific context, a military college in Malaysia and therefore the study participants may not be representative of other university students around the world and the findings may not be generalizable to other contexts (eg, where antibiotics cannot be bought over the counter). The students were self-selecting as they could opt out of the study, and they also self-reported on their behaviors, therefore there could be some recall bias leading to respondents either over- or under-reporting SMA. The study sample was also relatively low and therefore more studies in different contexts with larger numbers and measuring actually observed behaviors would help to validate or refute the findings from this study. Furthermore, some participants did not complete all survey questions, hence the missing data in the results presentation. The cross-sectional study design used did not allow for the causal-effect relationship to be inferred or concluded from the results of this study. Finally, it was unclear what and how any educational interventions might have impacted on the findings; therefore, action research studies would also be useful to examine the impact on antibiotic usage of education on antibiotic resistance and appropriate use of antibiotics.

\section{Conclusions}

Currently, AMR is a global public health crisis which has often been ascribed to the indiscriminate, irrational use of antimicrobials by registered health practitioners and SMA. These study respondents are medical and non-medical military students of the public university, who should be relatively informed and educated about the risks of SMA and will probably be future leaders in the country. However, even amongst this group, almost 40\% (39.3\%) of respondents reported self-medicating with antibiotics. The most concerning finding was that $89 \%$ of the research 
participants felt that practicing SMA was a good or acceptable practice. Whilst these Malaysian students might not be representative of those in other contexts, the study highlights that more multi-center, well-designed prospective research studies are urgently required to confirm the issue and inform new health care and educational policies and strategies, which must include strict regulation of purchasing antibiotics over the counter.

\section{Key issues or findings}

- Self-medication of antibiotics (SMA) is a common problem, especially in low and middle-income countries

- It helps contribute to antimicrobial resistance and leads to a range of other health issues for individuals and health economies

- Medical students, particularly more senior students, are less likely to practice SMA than non-medical students, reflecting their deeper knowledge of antibiotic use and misuse

- Whilst multiple factors contribute to SMA, cost and convenience are common reasons, reflected in the findings from this study

- However, despite medical students being less likely to report SMA, $89 \%$ of all the students in the study felt SMA was a good or acceptable practice

- More educational, policy and regulatory interventions are required to increase knowledge about antibiotic use and prevent the purchase of antibiotics without prescription

\section{Acknowledgments}

The authors are very grateful to Dr. William Ba-Thein, Shantou-Oxford Clinical Research Unit, Shantou University Medical College, and the Department of Microbiology and Immunology, Shantou University Medical College, Shantou, Guangdong, People's Republic of China for their kind and necessary permission to utilize the study instrument. Researchers are also grateful to those students who participated in this study. This study obtained no financial support.

\section{Disclosure}

Dr. Md Anwarul Azim Majumder is the current Editor-inChief of the Advances in Medical Education and Practice journal for Dove Medical Press. The authors report no other conflicts of interest in this work.

\section{References}

1. World Health Organization. WHO Guidelines for the Regulatory Assessment of Medicinal Products for Use in Self-Medication. Geneva: WHO/EDM/QSM/00.1 WHO; 2000. Available from: http://apps.who.int/medicinedocs/pdf/s2218e/s2218e.pdf. Accessed May 29, 2018.

2. Alhomoud F, Aljamea Z, Almahasnah R, Alkhalifah K, Basalelah L, Alhomoud FK. Self-medication and selfprescription with antibiotics in the Middle East—do they really happen? A systematic review of the prevalence, possible reasons, and outcomes. Int $J$ Infect Dis. 2017;57:3-12. doi:10.1016/j. ijid.2017.01.014

3. Togoobaatar G, Ikeda N, Ali M, et al. Survey of non-prescribed use of antibiotics for children in an urban community in Mongolia. Bull World Health Organ. 2010;88(12):930-936. doi:10.2471/ BLT.10.079004

4. Reardon S. Antibiotic resistance sweeping developing world. Bacteria are increasingly dodging extermination as drug availability outpaces regulation. Nature. 2014;509:141-142. doi: $10.1038 / 509141 \mathrm{a}$

5. Wirtz VJ, Herrera-Patino JJ, Santa-Ana-Tellez Y, Dreser A, Elseviers M, Vander Stichele RH. Analyzing policy interventions to prohibit over-the-counter antibiotic sales in four Latin American countries. Trop Med Int Health. 2013;18(6):665-673. doi:10.1111/ tmi. 12096

6. Malaysian Pharmaceutical Society. From the President's Desk. Pharmacists pledge to be antibiotic guardians. Press Release. 2017. Available from: http://www.mps.org.my/newsmaster.cfm? $\&$ menuid $=191$ \&action $=$ view\&retrieveid $=7508$. Accessed June 19, 2018.

7. The Star Online. Medication must not be sold without prescription; 2016. Available from: https://www.thestar.com.my/ opinion/letters/2016/08/29/medication-must-not-be-sold-withoutprescription/. Accessed June 19, 2018.

8. Malaysian Pharmaceutical Society. Superbugs on the rise. National Pharmacy News; 2015. Available from: http://www. mps.org. $\mathrm{my} /$ newsmaster.cfm?\&menuid=36\&action=view\&retrie veid=7183. Accessed June 19, 2018.

9. Wolfe CM, Cohen B, Larson E. Prevalence and risk factors for antibiotic-resistant community-associated bloodstream infections. $J$ Infect Public Health. 2014;7(3):224-232. doi:10.1016/j. jiph.2014.01.001

10. Unemo M, Golparian D, Shafer WM. Challenges with gonorrhea in the era of multidrug and extensively drug resistance - are we on the right track? Expert Rev Anti Infect Ther. 2014;12 (6):653-656. doi:10.1586/14787210.2014.906902

11. Falcone M, Russo A, Giannella M, et al. Individualizing risk of multidrug-resistant pathogens in community-onset pneumonia. PLoS One. 2015;10(4):e0119528. doi:10.1371/journal.pone. 0119528

12. World Health Organization. Antimicrobial resistance. Key Facts; 2018. Available from: http://www.who.int/news-room /fact-sheets/detail/antimicrobial-resistance. Accessed June 19, 2018.

13. National Institute of Allergy and Infectious Diseases. MultidrugResistant Neisseria Gonorrhea. 2016. Available from: https:// www.niaid.nih.gov/research/multidrug-resistant-neisseriagonorrhoeae Accessed June 19, 2018.

14. Birger RB, Kouyos RD, Cohen T, et al. The potential impact of coinfection on antimicrobial chemotherapy and drug resistance. Trends Microbiol. 2015;23(9):537-544.

15. Ruiz ME. Risks of self-medication practices. Curr Drug Saf. 2010;5(4):315-323. 
16. Kiyingi KS, Lauwo JA. Drugs in the home: danger and waste. World Health Forum. 1993;14(4):381-384.

17. Rather IA, Kim BC, Bajpai VK, Parka YH. Self-medication and antibiotic resistance: crisis, current challenges, and prevention. Saudi J Biol Sci. 2017;24(4):808-812. doi:10.1016/j.sjbs.2017.01.004

18. Bennadi D. Self-medication: A current challenge. J Basic Clin Pharm. 2013;5(1):19-23. doi:10.4103/0976-0105.128253

19. Shah SJ, Ahmad H, Rehan RB, et al. Self-medication with antibiotics among non-medical university students of Karachi: a cross-sectional study. BMC Pharmacol Toxicol. 2014;15:74. doi:10.1186/2050-6511-15-74

20. Ventola CL. The Antibiotic Resistance Crisis: part 1: causes and Threats. Pharm Ther. 2015;40(4):277-283.

21. Littmann J, Viens AM. The ethical significance of antimicrobial resistance. Public Health Ethics. 2015;8(3):209-224. doi:10.1093/ phe/phv025

22. World Health Organization (WHO). Antibiotic resistance; 2018. Available from: http://www.who.int/news-room/fact-sheets/detail/ antibiotic-resistance. Accessed June 20, 2018.

23. Reardon S WHO warns against 'post-antibiotic' era? Agency recommends global system to monitor spread of resistant microbes; 2014. Available from: https://www.nature.com/news/who-warnsagainst-post-antibiotic-era-1.15135. Accessed June 20, 2018.

24. Viens AM, Littmann J. Is antimicrobial resistance a slowly emerging disaster? Public Health Ethics. 2015;8(3):255-265. doi: $10.1093 / \mathrm{phe} / \mathrm{phv} 015$

25. World Health organization. WHO's first global report on antibiotic resistance reveals serious, worldwide threat to public health. New WHO report provides the most comprehensive picture of antibiotic resistance to date, with data from 114 countries. News release; 2014. Available from: http://www.who.int/mediacentre/ news/releases/2014/amr-report/en/. Accessed June 20, 2018.

26. McCarthy M Chief medical officer dame sally davies: resistance to antibiotics risks health "Catastrophe" to rank with terrorism and climate change. The Independent; 2013 Available from: https://www.independent.co.uk/news/science/ chief-medical-officer-dame-sally-davies-resistance-toantibiotics-risks-health-catastrophe-to-rank-8528442.html. Accessed June 22, 2018.

27. Sample I Antibiotic-resistant diseases pose "Apocalyptic" threat, top expert says. The Guardian; 2013. Available from https://www. theguardian.com/society/2013/jan/23/antibiotic-resistant-diseasesapocalyptic-threat. Accessed June 22, 2018.

28. Hakanen A, Kaartinen JJJL National action plan on antimicrobial resistance 2017-2021. Available from: https://ec.europa.eu/health/ $\mathrm{amr} / \mathrm{sites} / \mathrm{amr} /$ files/amr_nap_finland_en.pdf. Accessed June 22, 2018.

29. Fair RJ, Tor Y. Antibiotics and bacterial resistance in the $21 \mathrm{st}$ century. Perspect Med Chem. 2014;6:25-64.

30. Llor C, Bjerrum L. Antimicrobial resistance: risk associated with antibiotic overuse and initiatives to reduce the problem. Ther $A d v$ Drug Saf. 2014;5(6):229-241. doi:10.1177/20420986145554919

31. Yadav K, Prakas S. Antimicrobial Resistance (AMR): a global problem. Glob J Pub Health Epidemiol. 2016;3(1):120-138.

32. Tomb RM, Maclean M, Coia JE, MacGregor SJ, Anderson JG. Assessment of the potential for resistance to antimicrobial violet-blue light in Staphylococcus aureus. Antimicrob Resist Infect Control. 2017;6:100. doi:10.1186/s13756-017-0261-5

33. Ferry T, Perpoint T, Vandenesch F, Etienne J. Virulence determinants in Staphylococcus aureus and their involvement in clinical syndromes. Curr Infect Dis Rep. 2005;7(6):420-428.

34. Munita JM, Arias CA. Mechanisms of antibiotic resistance. Microbiol Spectr. 2016;4(2). doi:10.1128/microbiolspec.VMBF0016-2015

35. Fymat AL. Antibiotics and antibiotic resistance. Biomed J Sci \& Tech Res. 2017;1(1):1-16.
36. Boswihi SS, Udo EE. Methicillin-resistant Staphylococcus aureus: an update on the epidemiology, treatment options, and infection control. Curr Med Res Prac. 2018;8(1):18-24. doi:10.1016/j. cmrp.2018.01.001

37. Chen CJ, Huang YC. New epidemiology of Staphylococcus aureus infection in Asia. Clin Microbiol Infect. 2014;20(7):605-623. doi:10.1111/1469-0691.12705

38. Sowash MG, Uhlemann A-C. Community-associated methicillin-resistant Staphylococcus aureus case studies. Methods Mol Biol. 2014;1085:25-69. doi:10.1007/978-1-62703664-1_2

39. Ray P, Gautam V, Singh R. Methicillin-resistant Staphylococcus aureus (MRSA) in developing and developed countries: implications and solutions. Regional Health Forum. 2011;15 (1):74-82.

40. Chouhan K, Prasad SB. Self-medication and their consequences: a challenge to health professional. Asian J Pharm Clin Res. 2016;9(2):314-317.

41. Centers for Disease Control and Prevention. Biggest Threats. 1600 Clifton Road Atlanta, GA 30329-4027 USA; 2018. Available from: https://www.cdc.gov/drugresistance/biggest threats.html. Accessed June 24, 2018.

42. The Star Online. Antibiotic resistance in M'sia worrying; 2015. Available from: https://www.thestar.com.my/news/nation/ 2015/11/17/superbugs-on-the-rise-data-shows-pathogensincreasing-resistance-to-antibiotics/. Accessed June 24, 2018

43. The Borneo Post Online. Antibiotic-resistant bacteria now a serious global health threat; 2016. Available from: http://www. theborneopost.com/2016/11/19/antibiotic-resistant-bacteria-now -a-serious-global-health-threat/. Accessed June 24, 2018.

44. Gelband H, Miller-Petrie M, Pant S, et al. The state of the world's antibiotics. The Center for Disease Dynamics, Economics \& Policy (CDDEP); 2015 Available from: https://www.cddep.org/publica tions/state_worlds_antibiotics_2015. Accessed June 24, 2018.

45. Ministry of Health Malaysia. Malaysian Statistics on Medicines $2009 \&$ 2010. Pharmaceutical Services Division and Clinical Research Centre. Kuala Lumpur 2014.

46. IMU News. The pulse of IMU. Antibiotics: friend or Foe? 2017. Available from: http://imunews.imu.edu.my/health/antibioticsfriend-foe/. Accessed June 24, 2018.

47. Centers for Disease Control and Prevention. Newly Reported Gene, mcr -1, Threatens Last-Resort Antibiotics. 1600 Clifton Road Atlanta, GA 30329-4027 USA; 2018. Available from: https://www.cdc.gov/drugresistance/mcr1.html. Accessed June 24, 2018

48. Zellweger RM, Carrique-Mas J, Limmathurotsakul D, Day NPJ, Thwaites GE, Baker S. Southeast Asia Antimicrobial Resistance Network. A current perspective on antimicrobial resistance in Southeast Asia. J Antimicrob Chemother. 2017;72 (11):2963-2972. doi:10.1093/jac/dkx260

49. Premanandh J, Samara BS, Mazen AN. Race against antimicrobial resistance requires coordinated action - an overview. Front Microbiol. 2015;6:1536.

50. Department of Health and Social Care. Prime Minister warns of global threat of antibiotic resistance. Prime Minister's Office, 10 Downing Street; 2014. Available from: https://www.gov.uk/gov ernment/news/prime-minister-warns-of-global-threat-of-antibiotic -resistance. Accessed June 25, 2018.

51. Spellberg B, Guidos R, Gilbert D, et al. Infectious Diseases Society of America. The epidemic of antibiotic-resistant infections: a call to action for the medical community from the infectious diseases society of America. Clin Infect Dis. 2008;46 (2):155-164. doi:10.1086/524891

52. Viswanathan VK. Off-label abuse of antibiotics by bacteria. Gut Microbes. 2014;5(1):3-4. doi:10.4161/gmic.28027 
53. Read AF, Woods RJ. Antibiotic resistance management. Evol Med Public Health. 2014;2014(1):147. doi:10.1093/emph/eou024

54. The antibiotic alarm. Nature. 2013;495(7440):141. doi:10.1038/ 495141a

55. Lushniak BD. Antibiotic resistance: a public health crisis. Public Health Rep. 2014;129(4):314-316. doi:10.1177/ 003335491412900402

56. Gross M. Antibiotics in crisis. Curr Biol. 2013;23(24):R1063R1065.

57. Piddock LJ. The crisis of no new antibiotics - what is the way forward? Lancet Infect Dis. 2012;12(3):249-253. doi:10.1016/ S1473-3099(11)70316-4

58. Bartlett JG, Gilbert DN, Spellberg B. Seven ways to preserve the miracle of antibiotics. Clin Infect Dis. 2013;56(10):1445-1450. doi:10.1093/cid/cit070

59. Michael CA, Dominey-Howes D, Labbate M. The antibiotic resistance crisis: causes, consequences, and management. Front Public Health. 2014;2:145. doi:10.3389/fpubh.2014.0 0145

60. Maragakis LL, Perencevich EN, Cosgrove SE. Clinical and economic burden of antimicrobial resistance. Expert Rev Anti Infect Ther. 2008;6(5):751-763. doi:10.1586/14787210.6. 5.751

61. Cosgrove SE. The relationship between antimicrobial resistance and patient outcomes: mortality, length of hospital stay, and health care costs. Clin Infect Dis. 2006;42(Suppl 2):S82-89. doi: $10.1086 / 499406$

62. Li B, Webster TJ. Bacteria antibiotic resistance: new challenges and opportunities for Implant-Associated Orthopedic Infections. J Ortho Res. 2018;36(1):22-32.

63. Schwaber MJ, Navon-Venezia S, Kaye KS, Ben-Ami R, Schwartz D, Carmeli Y. Clinical and economic impact of bacteremia with extended-spectrum- $\beta$-lactamase-producing Enterobacteriaceae. Antimicrob Agents Chemother. 2006;50(4):1257-1262. doi:10.1128/ AAC.50.4.1257-1262.2006

64. Lautenbach E, Patel JB, Bilker WB, Edelstein PH, Fishman NO. Extended-spectrum $\beta$-lactamase-producing Escherichia coli and Klebsiella pneumoniae: risk factors for infection and impact of resistance on outcomes. Clin Infect Dis. 2001;32(8):1162-1171. doi: $10.1086 / 319757$

65. Lodise TP, McKinnon PS. Clinical and economic impact of methicillin resistance in patients with Staphylococcus aureus bacteremia. Diagn Microbiol Infect. Dis. 2005;52(2):113-122. doi:10.1016/j.diagmicrobio.2005.02.007

66. Cosgrove SE, Qi Y, Kaye KS, Harbarth S, Karchmer AW, Carmeli Y. The impact of methicillin resistance in Staphylococcus aureus bacteremia on patient outcomes: mortality, length of stay, and hospital charges. Infect Control Hosp Epidemiol. 2005;26(2):166-174. doi:10.1086/502522

67. Vergis EN, Hayden MK, Chow JW, et al. Determinants of vancomycin resistance and mortality rates in enterococcal bacteremia. A prospective multicenter study. Ann Intern Med. 2001;135 (7):484-492

68. Kwon KT, Oh WS, Song JH, et al. Impact of imipenem resistance on mortality in patients with Acinetobacter bacteraemia. $J$ Antimicrob Chemother. 2007;59(3):525-530. doi:10.1093/jac/dk1499

69. Young LS, Sabel AL, Price CS. Epidemiologic, clinical, and economic evaluation of an outbreak of clonal multidrug-resistant Acinetobacter baumannii infection in a surgical intensive care unit. Infect Control Hosp Epidemiol. 2007;28(11):1247-1254. doi: $10.1086 / 521660$

70. Wilson SJ, Knipe CJ, Zieger MJ, et al. Direct costs of multidrug-resistant Acinetobacter baumannii in the burn unit of a public teaching hospital. Am J Infect Control. 2004;32 (6):342-344. doi:10.1016/j.ajic.2004.02.008
71. Aloush V, Navon-Venezia S, Seigman-Igra Y, Cabili S, Carmeli Y. Multidrug-resistant Pseudomonas aeruginosa: risk factors and clinical impact. Antimicrob Agents Chemother. 2006;50(1):43-48. doi:10.1128/AAC.50.1.43-48.2006

72. Abasiubong F, Bassey EA, Udobang JA, Akinbami OS, Udoh SB, Idung AU. Self-Medication: potential risks and hazards among pregnant women in Uyo, Nigeria. Pan Afr Med J. 2012;13:15.

73. Al Rasheed A, Yagoub U, H A, et al. Prevalence and predictors of self-medication with antibiotics in Al Wazarat Health Center, Riyadh City, KSA. Biomed Res Int. 2016;2016:1-8. Article ID 3916874. doi:10.1155/2016/3916874

74. Aziz MM, Masood I, Yousaf M, Saleem H, Ye D, Fang Y. Pattern of medication selling and self-medication practices: a study from Punjab, Pakistan. PLoS One. 2018;13(3):e0194240. doi:10.1371/ journal.pone.0194240

75. Arshad MS, Rasool MF, Ijaz M, Hussain A. Evaluation of antibiotic use behavior in cold and flu amongst the students of Bahauddin Zakariya University Multan Pakistan. Pak J Pharm. 2010;23(2):15-22.

76. Anwar M, Green JA, Norris P, Bukhari NI. Self-medication, home remedies, and spiritual healing: common responses to everyday symptoms in Pakistan. Health Psychol Behav Med. 2015;3(1):281-295. doi:10.1080/21642850.2015.1088387

77. Saleem Z, Saeed H, Ahmad M, et al. Antibiotic self-prescribing trends, experiences and attitudes in upper respiratory tract infection among pharmacy and non-pharmacy students: a study from Lahore. PLoS One. 2016;11(2):e0149929. doi:10.1371/journal.pone.0149929

78. Guinovart MC, Figueras A, Llop JC, Llor C. Obtaining antibiotics without prescription in Spain in 2014: even easier now than 6 years ago. J Antimicrob Chemother. 2015;70(4):1270-1271. doi:10.1093/jac/dku526

79. Kalungia AC, Burger J, Godman B, Costa JO, Simuwelu C. Non-prescription sale and dispensing of antibiotics in community pharmacies in Zambia. Expert Rev Anti Infect Ther. 2016;14(12):1215-1223. doi:10.1080/14787210. 2016.1227702

80. Widayati A, Suryawati S, de Crespigny C, Hiller JE. Selfmedication with antibiotics in Yogyakarta City Indonesia: a cross sectional population-based survey. BMC Res Notes. 2011;4:491. doi:10.1186/1756-0500-4-491

81. Bilal M, Haseeb A, Khan MH, et al. Self-medication with antibiotics among people dwelling in rural areas of Sindh. J Clin Diagn Res. 2016;10(5):OC08-OC13. doi:10.7860/JCDR/2016/ 18294.7730

82. Kumar N, Kanchan T, Unnikrishnan B, et al. Perceptions and practices of self-medication among medical students in Coastal South India. PLoS One. 2013;8(8):e72247. doi:10.1371/journal. pone. 0072247

83. Núnez $M$, Tresierra-Ayala M, Gil-Olivares F. Antibiotic self-medication in university students from Trujillo, Peru. Medicina Universitaria. 2017;18(73):205-209. doi:10.1016/j. rmu.2016.10.003

84. Jawahir S, Aziz NA. Self-medication among adult population in Selangor, Malaysia. Int J Pharm Pharm Sci. 2017;9(5):268-274. doi:10.22159/ijpps.2017v9i5.16445

85. Biswas M, Roy MN, Manik MI, et al. Self medicated antibiotics in Bangladesh: a cross-sectional health survey conducted in the Rajshahi City. BMC Public Health. 2014;14:847. doi:10.1186/ 1471-2458-14-847

86. Moise K, Bernard JJ, Henrys JH. Evaluation of antibiotic self-medication among outpatients of the state university hospital of Port-Au-Prince, Haiti: a cross-sectional study. Pan Afr Med J. 2017;28:4. doi:10.11604/PAMJ. SUPP.2017.28.1.2486 
87. Eticha T, Mesfin K. Self-medication practices in Mekelle, Ethiopia. PLoS One. 2014;9(5):e97464. doi:10.1371/journal. pone.0097464

88. Aqeel T, Shabbir A, Basharat H, et al. Prevalence of self-medication among urban and rural population of Islamabad, Pakistan. Trop J Pharm Res. 2014;13(4):627-663. doi:10.4314/ tjpr.v13i4.22

89. Riaza H, Godmanb B, Hussaind S, et al. (2015) Prescribing of bisphosphonates and antibiotics in Pakistan: challenges and opportunities for the future. J Pharm Health Serv Res. 2015;6 (2):111-121. doi:10.1111/jphs.12091

90. Nepal G, Bhatta S. Self-medication with antibiotics in WHO Southeast Asian Region: a systematic review. Cureus. 2018;10 (4):e2428.

91. Wang X, Lin L, Xuan Z, Li L, Zhou X. Keeping antibiotics at home promotes self-medication with antibiotics among Chinese University Students. Int J Environ Res Public Health. 2018;15(4): E687. doi:10.3390/ijerph15061188

92. Prestinaci F, Pezzotti P, Pantosti A. Antimicrobial resistance: a global multifaceted phenomenon. Pathog Glob Health. 2015;109(7):309-318. doi:10.1179/2047773215Y.0000000030

93. Roca I, Akova M, Baquero F, et al. The global threat of antimicrobial resistance: science for intervention. New Microbes New Infect. 2015;6:22-29. doi:10.1016/j.nmni.2015.02.007

94. Ali AN, Kai JTTK, Keat CC, Dhanaraj SA. Self-medication practices among health care professionals in a Private University, Malaysia. Int Curr Pharm J. 2012;1(10):302-310. doi:10.3329/icpj.v1i10.11846

95. Rosen IM, Christie JD, Bellini LM, Asch DA. Health and health care among housestaff in Four U.S. Internal Medicine Residency Programs. J Gen Int Med. 2000;15(2):116-121. doi:10.1046/ j.1525-1497.2000.11218.x

96. Shankar PR, Partha P, Shenoy N. Self-medication and non-doctor prescription practices in Pokhara Valley, Western Nepal. A questionnaire based study. BMC Fam Prac. 2002;3:17. doi:10.1186/1471-2296-3-17

97. Gillani AH, Ji W, Hussain W, et al. Antibiotic self-medication among Non-Medical University Students in Punjab, Pakistan: a cross-sectional survey. Int J Environ Res Public Health. 2017;14 (10):1152. doi:10.3390/ijerph14101152

98. Raosoft Sample Size Calculator. Available from: http://www.rao soft.com/samplesize.html. Accessed June 30, 2018.

99. Pan H, Cui B, Zhang D, Farrar J, Law F, Ba-Thein W. Prior knowledge, older age, and higher allowance are risk factors for self-medication with antibiotics among university students in Southern China. PLoS One. 2012;7(7):e413.

100. Nunnally JC. Psychometric Theory. 2nd ed. New York: McGrawHill; 1978.

101. Barman MP, Hazarika J, Kalita A. Reliability and validity of Assamese version of EORTC QLQ-C30 questionnaire for studying the quality of life of cancer patients of Assam. World Appl Sci J. 2012;17(5):672-678.

102. Suleiman AK. Self-medication and the advisory role of pharmacists in Riyadh, Saudi Arabia. Arch Pharma Pract. 2013;4 (4):180-185. doi:10.4103/2045-080X.123228

103. Banerjeea R, Starke JR. What tuberculosis can teach us about combating multidrug-resistant Gram-negative bacilli? J Clin Tuberc Other Mycobact Dis. 2016;3:28-34. doi:10.1016/j. jctube.2016.03.004

104. Haque M, Lutf SN, Othman NS, Lugova H, Abdullah SL. Empathy level among the medical students of National Defence University of Malaysia consuming Toronto empathy scale. Acta Med Int. 2018;5(1):24-30. doi:10.4103/ami. ami_73 17
105. Haque M, Othman NSAB, Lutf SNN, et al. Evaluation of out-patient care educational environment of National Defence University, Malaysia utilizing the ACLEEM Inventory. $J$ Basic Clin Health Sci. 2018;2(2):45-52. doi:10.30621/ jbachs.2018.412

106. Lau T What's the Average Age For Men and Women to Get Married? Asia Wedding Network; 2017. Available from: http:// asiaweddingnetwork.com/en/magazine/expert-advice/1873average-marriage-age-women-men-asia. Accessed July 4, 2018.

107. Pesuruhjaya Penyemak Undang-Undang, Malaysia Di bawah Kuasa Akta Penyemakan Undang-Undang 1968. UndangUndang Malaysia. Cetakan Semula. Akta 77. Akta angkatan Tentera 1972. Mengandungi segala pindaan hingga 1 Januari 2006, Percetakan Nasional Malaysia Berhad. (Commissioner of Legal Review, Malaysia Under the Law Revision Act 1968. Laws of Malaysia. Reprinted. Act 77. Armed Forces Act 1972. Contains all amendments up to January 1, 2006). National printing of Malaysia Ltd. Available from: http:/www.agc.gov.my/agc portal/uploads/files/Publications/LOM/MY/Akta\%2077.pdf Accessed July 4, 2018.

108. Lewison G, Kumar S, Wong C-Y, Roe P, Webber R. The contribution of ethnic groups to Malaysian scientific output, 1982-2014, and the effects of the new economic policy. Scientometrics. 2016;109 (3):1877-1893. doi:10.1007/s11192-016-2139-3

109. CBS News. CDC: 4 out of 5 Americans prescribed antibiotics each year; 2013. Available from: https:/www.cbsnews.com/news/ cdc-4-out-of-5-americans-prescribed-antibiotics-each-year/. Accessed July 4, 2018.

110. Klein EY, Van Boeckel TP, Martinez EM, et al. Global increase and geographic convergence in antibiotic consumption between 2000 and 2015. Proc National Acad Sci. 2018;115(15):E3463E3470.

111. Shubha R, Savkar MK, Manjunath GN. Self-medication pattern among dentists with antibiotics. J Evol Med Dent Sci. 2013;2 (46):9037-9041. doi:10.14260/jemds/1567

112. Seam MOR, Bhatta R, Saha BL, et al. Assessing the perceptions and practice of self-medication among Bangladeshi undergraduate pharmacy students. Pharmacy (Basel). 2018;6(1):pii: E6. doi:10.3390/pharmacy6010006

113. Tshokey $\mathrm{T}$, Adhikari D, Tshering $\mathrm{T}$, Wangmo S, Wangdi $\mathrm{K}$. Assessing the knowledge, attitudes, and practices on antibiotics among the general public attending the outpatient pharmacy units of hospitals in Bhutan: a cross-sectional survey. Asia Pac J Public Health. 2017;29(7):580-588. doi:10.1177/1010539517734682

114. Grigoryan L, Burgerhof JG, Haaijer-Ruskamp FM, SAR group, et al. Is self-medication with antibiotics in Europe driven by prescribed use? J Antimicrob Chemother. 2007;59(1):152-156. doi:10.1093/jac/dk1457

115. Alam N, Saffoon N, Uddin R. Self-medication among medical and pharmacy students in Bangladesh. BMC Res Notes. 2015;8:763. doi:10.1186/s13104-015-1737-0

116. Selvaraj K, Kumar SG, Ramalingam A. Prevalence of self-medication practices and its associated factors in Urban Puducherry, India. Perspect Clin Res. 2014;5(1):32-36. doi:10.4103/2229-3485.124569

117. Shehadeh M, Suaifan G, Darwish RM, Wazaify M, Zaru L, Alja'fari S. Knowledge, attitudes and behavior regarding antibiotics use and misuse among adults in the community of Jordan. A Pilot Study Saudi Pharm J. 2012;20(2):125-133. doi:10.1016/j. jsps.2011.11.005

118. Mao W, Vu H, Xie Z, Chen W, Tang S. Systematic review on irrational use of medicines in China and Vietnam. Mendelson JE, Ed. PLoS ONE. 2015;10(3):e0117710. doi:10.1371/journal. pone. 0117710 
119. Nathan C, Cars O. Antibiotic resistance-problems, progress, and prospects. N Engl J Med. 2014;371(19):1761-1763. doi:10.1056/ NEJMp1408040

120. Shehnaz SI, Khan N, Sreedharan J, Issa KJ, Arifulla M. Selfmedication and related health complaints among expatriate high school students in the United Arab Emirates. Pharm Pract. 2013;11(4):211-218. doi:10.4321/S1886-36552013000400006

121. Alghadeer S, Aljuaydi K, Babelghaith S, Alhammad A, Alarifi MN. Self-medication with antibiotics in Saudi Arabia. Saudi Pharm J. 2018;26(5):719-724. doi:10.1016/j.jsps.2018.02.018

122. Yao MW How bad is the counterfeit drug problem in Malaysia? MIMS Today; 2017. Available from https://today.mims.com/howbad-is-the-counterfeit-drug-problem-in-malaysia-. Accessed July $5,2018$.

123. World Health Organization. Does stopping a course of antibiotics early lead to antibiotic resistance? 2017. Available from: http:// www.who.int/features/qa/stopping-antibiotic-treatment/en/. Accessed July 5, 2018.

124. Ayalew MB. Self-medication practice in Ethiopia: a systematic review. Patient Prefer Adherence. 2017;11:401-413. doi:10.2147/ PPA.S131496

125. Sado E, Kassahun E, Bayisa G, Gebre M, Tadesse A, Mosisa B. Epidemiology of self-medication with modern medicines among health care professionals in Nekemte town, western Ethiopia. BMC Res Notes. 2017;10(1):533. doi:10.1186/ s13104-017-2865-5

126. Okeke IN, Lamikanra A, Edelman R. Socioeconomic and behavioral factors leading to acquired bacterial resistance to antibiotics in developing countries. Emerg Infect Dis. 1999;5(1):18-27. doi:10.3201/eid0501.990103

127. Awad A, Eltayeb I, Matowe L, Thalib L. Self-medication with antibiotics and antimalarials in the community of Khartoum State, Sudan. J Pharm Pharm Sci. 2005;8(2):326-331.

128. Mehta RK, Sharma S. Knowledge, attitude and practice of self-medication among medical students. IOSR J Nurs Health Sci. 2015;4(1):89-96.

129. Sontakke SD, Bajait CS, Pimpalkhute SA, Jaiswal KM, Jaiswal SR. Comparative study of evaluation of self-medication practices in first and third year medical students. Int $J$ Biol Med Res. 2011;2:561-564.

130. Ayanwale MB, Okafor IP, Odukoya OO. Self-medication among rural residents in Lagos, Nigeria. J Med Trop. 2017;19(1):65-71. doi:10.4103/jomt.jomt_51_16

131. Mostafa-Hedeab G. Knowledge, attitude, and behaviors toward antibiotics of non-medical students Jouf University, Saudi Arabia. Asian J Pharm Clin Res. 2018;11(8):294-299. doi:10.22159/ ajpcr.2018.v11i8.26308

132. Bebell LM, Muiru AN. Antibiotic use and emerging resistance: how can resource-limited countries turn the tide? Glob Heart. 2014;9(3):347-358. doi:10.1016/j.gheart.2014.08.009

133. Antimicrobial Use HM, Prescribing A. Resistance in selected ten selected developing countries: a brief overview. Asian J Pharm Clin Res. 2017;10(8):37-45. doi:10.22159/ajpcr.2017.v10i8.19468

134. Lawes T, Lopez-Lozano JM, Nebot CA, Macartney G, Subbarao-Sharma R. Effects of national antibiotic stewardship and infection control strategies on hospital-associated and community-associated meticillin-resistant Staphylococcus aureus infections across a region of Scotland: a non-linear time-series study. Lancet Infect Dis. 2015;15(12):1438-1449. doi:10.1016/S1473-3099(15)00315-1
135. Lawes T, Lopez-Lozano JM, Nebot CA, et al. Effect of a national $4 \mathrm{C}$ antibiotic stewardship intervention on the clinical and molecular epidemiology of Clostridium difficile infections in a region of Scotland: a non-linear time-series analysis. Lancet Infect Dis. 2017;17(2):194-206. doi:10.1016/S14733099(16)30397-8

136. Gebrekirstos NH, Workneh BD, Gebregiorgis YS, et al. Nonprescribed antimicrobial use and associated factors among customers in drug retail outlet in Central Zone of Tigray, northern Ethiopia: a cross-sectional study. Antimicrob Resist Infect Control. 2017;6:70. doi:10.1186/s13756-017-0227-7

137. Lukovic JA, Miletic V, Pekmezovic T, et al. Self-medication practices and risk factors for self-medication among medical students in Belgrade, Serbia. PLoS One. 2014;9(12):e114644. doi:10.1371/journal.pone.0114644

138. Webster P. Antibiotic overprescribing a growing problem. Cmaj. 2017;189(5):E222.

139. Fleming-Dutra KE, Hersh AL, Shapiro DJ, et al. Prevalence of inappropriate antibiotic prescriptions among US Ambulatory Care Visits, 2010-2011. JAMA. 2016;315(17):1864-1873. doi:10.1001/ jama.2016.4151

140. Harris AM, Hicks LA, Qaseem A. High value care task force of the American College of Physicians and for the centers for disease control and prevention. Appropriate antibiotic use for acute respiratory tract infection in adults: advice for high-value care from the American College of Physicians and the Centers for Disease Control and Prevention. Ann Intern Med. 2016;164 (6):425-434. doi:10.7326/M15-1840

141. Fiore DC, Fettic LP, Wright SD, Ferrara BR. Antibiotic overprescribing: still a major concern. J Fam Pract. 2017;66 (12):730-736.

142. Haque M, Sartelli M, Haque SZ. Dental Infection and. Resistance - global Health consequences. Dent J. 2019;7(1):22. doi: $10.3390 /$ dj7010022

143. Barlam TF, Soria-Saucedo R, Cabral HJ, Kazis LE. Unnecessary antibiotics for acute respiratory tract infections: association with care setting and patient demographics. Open Forum Infect Dis. 2016;3(1):ofw045. doi:10.1093/ofid/ofw045

144. Grijalva CG, Nuorti JP, Griffin MR. Antibiotic prescription rates for acute respiratory tract infections in US ambulatory settings. JAMA. 2009;302(7):758-766. doi:10.1001/ jama.2009.1163

145. McCaig LF, Hughes JM. Trends in antimicrobial drug prescribing among office-based physicians in the United States. JAMA. 1995;273(3):214-219.

146. Haque M, Rahman NAA, McKimm J, et al. A cross-sectional study evaluating the knowledge and beliefs about, and the use of antibiotics amongst Malaysian university student. Expert Rev Anti Infect Ther. 2019;1-10. doi:10.1080/ 14787210.2019 .1581607 


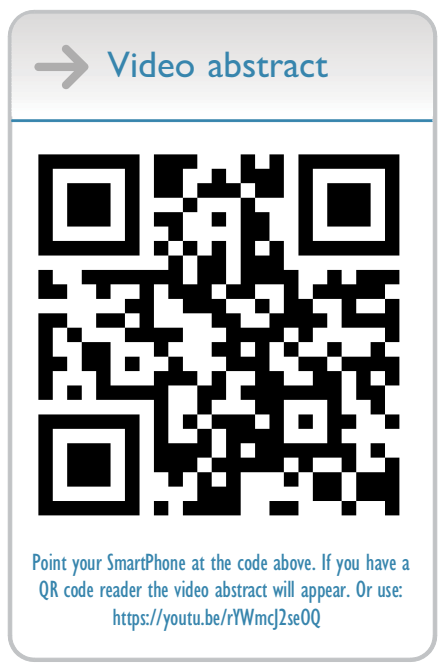

Infection and Drug Resistance

Dovepress

\section{Publish your work in this journal}

Infection and Drug Resistance is an international, peer-reviewed openaccess journal that focuses on the optimal treatment of infection (bacterial, fungal and viral) and the development and institution of preventive strategies to minimize the development and spread of resistance. The journal is specifically concerned with the epidemiology of

antibiotic resistance and the mechanisms of resistance development and diffusion in both hospitals and the community. The manuscript management system is completely online and includes a very quick and fair peerreview system, which is all easy to use. Visit http://www.dovepress.com/ testimonials.php to read real quotes from published authors. 